\title{
Efisiensi Penggunaan Grey Water dan Air Hujan dalam Rangka Menurunkan Tingkat Penggunaan Air Baku
}

\author{
Efficiency in the Use of Grey Water and Rainwater in Order \\ to Reduce Raw Water Use
}

\author{
MUHAMAD YUSUP HIDAYAT, RIDWAN FAUZI, ALFONSUS H HARIANJA, \\ GRACE SEREPINA SARAGIH
}

\author{
Pusat Penelitian dan Pengembangan Kualitas dan Laboratorium Lingkungan \\ Kawasan Puspiptek Gedung 210, Tangerang Selatan, 15314, Indonesia \\ Email: yusup.fairuz@gmail.com
}

\begin{abstract}
The population growth rate in big cities such as Jakarta and its satellite cities has a correlation that is directly proportional to the level of clean water consumption. The biggest consumption of clean water is generally used for domestic household needs. However, the use of clean water is still not efficient. Therefore, the efficiency of water-saving needs to be carried out by utilizing sources that have not been optimally used, for example, greywater and rainwater. The purpose of this study is to determine the level of water usage in 3 (three) types of housing and the level of efficiency of utilization of domestic wastewater (greywater) and rainfall $(\mathrm{CH})$ in reducing the use of clean water. This research was performed in the Villa Bintang Mas residential area in the City of South Tangerang, the Villa Bintang Mas residential area in the City of Depok, and the Selakopi Hijau/Forestry residential area in the City of Bogor. Data collection was conducted by a series of surveys using a questionnaire on the sample of a household. The results show that the data processing needs of clean water in three residentials range of values between \pm 158.84 Liters/person/day up to \pm 215.38 Liters/person/day. The level of efficiency of the utilization of greywater and rainwater in reducing the usage of clean water in three housing ranges from $21.12 \%$ to $58.47 \%$
\end{abstract}

Keywords: Domestic waste, the use of clean water

\begin{abstract}
ABSTRAK
Tingkat pertumbuhan penduduk di kota-kota besar seperti jakarta dan kota-kota satelitnya memiliki korelasi yang berbanding lurus dengan tingkat konsumsi air bersih yang dimanfaatkan oleh masyarakat. Konsumsi air bersih terbesar adalah untuk kebutuhan domestik rumah tangga. Penggunaan air bersih saat ini masih belum mengikuti kaidah efisiensi dalam penggunaannya, untuk itu efisiensi penghematan air perlu segera dilakukan dengan memanfaatkan sumber-sumber lain yang belum termanfaatkan, antara lain air limbah domestik rumah tangga (grey water) dan air hujan. Tujuan dari penelitian ini adalah mengetahui tingkat pemakaian air di 3 (tiga) tipe perumahan,serta tingkat efisiensi pemanfaatan air limbah domestik rumah tangga (grey water) serta curah hujan $(\mathrm{CH})$ dalam menurunkan pemakaian air bersih. Penelitian ini dilaksanakan di Perumahan Villa Bintang Mas, Kota Tangerang Selatan, Perumahan Permata Depok, Kota Depok, dan Perumahan Selakopi Hijau/Kehutanan, Kota Bogor. Pengambilan data dilakukan dengan cara survei menggunakan kuesioner pada rumah tangga yang menjadi sampel. Hasil pengolahan data memperlihatkan bahwa kebutuhan air bersih di tiga perumahan berkisar pada rentang nilai antara $\pm 158,84 \mathrm{Liter} / O r a n g /$ Hari sampai dengan \pm 215.38 Liter/Orang/Hari. Tingkat efisiensi pemanfaatan grey water dan air hujan dalam mengurangi pemakaian air bersih di tiga perumahan berkisar antara $21,12 \%$ hingga $58,47 \%$.
\end{abstract}

Kata kunci: Limbah domestik, penggunaan air bersih

\section{PENDAHULUAN}

\subsection{Latar Belakang}

Tingkat pertumbuhan penduduk di kota-kota besar memiliki korelasi yang berbanding lurus dengan tingkat konsumsi air yang dimanfaatkan oleh masyarakat. Konsumsi air bersih yang terbesar salah satunya adalah untuk pemenuhan kebutuhan domestik rumah tangga ${ }^{(1)}$. Untuk kota metropolitan seperti Jakarta, Bandung dan Tangerang Selatan yang berpenduduk lebih dari 1.000 .000 orang, diperkirakan kebutuhan air sebesar > 150 liter/orang/hari(2). Oleh karena itu dapat diperkirakan bahwa kebutuhan air untuk kebutuhan domestik di 1 (satu) kota metropolitan sebesar $150.000 \mathrm{~m}^{3} / \mathrm{hari}$. 
Pada kota-kota besar, pemenuhan akan air bersih banyak dipenuhi oleh Perusahaan Daerah Air Minum (PDAM) dan sumber air tanah. Data PAM Jaya Jakarta, saat ini kebutuhan air di Jakarta mencapai 26.000 liter per detik, sedangkan jumlah pasokan yang bisa dipenuhi, hanya sekitar 12.000 liter per detik ${ }^{(3)}$. Data di Perumahan Villa Mutiara kota Tangerang Selatan menunjukan bahwa kebutuhan masyarakat akan air tanah sangat tinggi, sehingga menyebabkan sumur-sumur dangkal yang tadinya kedalaman $20 \mathrm{~m}$, namun saat ini sudah mencapai $60 \mathrm{~m}^{(4)}$. Dampak jangka panjang dapat menurunkan muka air tanah dan menyebabkan krisis air.

Krisis air pada wilayah-wilayah perkotaan sering kali diakibatkan oleh penggunaan air bersih yang tidak mengikuti pola-pola efisien. Masih banyak pemanfaatan sumber air baku yang dilakukan hanya satu kali penggunaan, padahal pada beberapa aktivitas konsumsi air sehari-hari masih ada yang bisa memanfaatkan air limbah air domestik dari aktivitas konsumsi yang pertama yang tidak membutuhkan kualitas air yang baik. Hal ini menunjukan potensi pemanfaatan air limbah domestik sisa buangan rumah tangga (grey water) cukup tinggi. Menurut Nakagawa et al. komposisi volume buangan air limbah domestik untuk negara berkembang adalah $70 \%$ grey water dan $30 \%$ blackwater (air limbah yang berakhir di septic tank)(5).

Disamping pemanfaatan grey water, salah satu sumber potensi air yang belum termanfaatkan secara maksimal, yaitu air hujan. Potensi air hujan, pada wilayah yang tergolong Curah Hujan $(\mathrm{CH})$ tinggi, masih banyak yang belum dimanfaatkan secara maksimal. Pada wilayah-wilayah yang potensial, keberadaan air hujan sangat bermanfaat dalam menggantikan kebutuhan akan air bersih untuk konsumsi rumah tangga.

Untuk itu efisiensi penggunaan air dalam pemenuhan kebutuhan masyarakat perlu segera dilakukan melalui perubahan pola konsumsi air. Selain itu, perlu diikuti perubahan gaya hidup masyarakat dan penerapan prinsip-prinsip pola konsumsi yang berkelanjutan. Perubahan ini diharapkan dapat mengurangi permasalahan kekurangan (krisis) sumberdaya air.

\subsection{Tujuan Penelitian}

Tujuan dari penelitian ini adalah mengetahui tingkat pemakaian air di 3 (tiga) tipe perumahan, serta tingkat efisiensi pemanfaatan air limbah domestik rumah tangga (grey water) serta air hujan dalam menurunkan pemakaian air bersih.

\section{BAHAN DAN METODE}

\subsection{Bahan}

Bahan yang digunakan adalah kuesioner. Alat yang digunakan, yaitu: alat tulis, stop watch dan tabung ukur $1.000 \mathrm{~mL}$.

\subsection{Metode}

Metode yang digunakan dalam penelitian ini adalah metode kuantitatif. Data yang diperoleh kemudian dianalisis dengan analisis regresi linier berganda (multiple linear regression analysis). Pada penelitian ini data yang dikumpulkan adalah data konsumsi air rumah tangga seharihari meliputi aktifitas mandi dan bersih-bersih, flushing dan urinal, aktifitas dapur dan memasak, aktifitas bersih-bersih dan ibadah pada tiga lokasi dan tipe perumahan. Selain data konsumsi air rumah tangga, juga diidentifikasi data air hujan potensial yang dapat tertampung oleh masingmasing rumah, nilainya dijumlahkan dengan aktifitas yang menghasilkan volume grey water yang dihasilkan dan digunakan sebagai substitusi/pengurangan nilai konsumsi air pada aktifitas sehari-hari rumah tangga.

Penelitian dilaksanakan pada bulan Juli sampai dengan November 2018. Pengambilan data dilakukan dengan cara survei menggunakan kuesioner pada rumah yang menjadi sampel. Lokasi penelitian berada di tiga lokasi perumahan yang menjadi lokasi kajian, yaitu Perumahan Villa Bintang Mas, Kota Tangerang Selatan, Perumahan Permata Depok, Kota Depok, dan Perumahan Selakopi Hijau/Kehutanan, Kota Bogor. Penelitian ini menggunakan nilai kritis dalam pengambilan jumlah responden sebesar $11,5 \%$. Penentuan responden dalam penelitian ini ditentukan berdasarkan perhitungan dengan menggunakan rumus Slovin sebagai berikut:

$$
n=\frac{N}{1+N e^{2}}
$$

Keterangan :

$n$ : jumlah sampel rumah

$\mathrm{N}$ : jumlah populasi perumahan

e : batas toleransi kesalahan (error tolerance)

Data pemakaian air bersih diperoleh dengan melakukan perhitungan antara jumlah populasi yang ada dikalikan dengan total kebutuhan air bersih per hari per liter. Kebutuhan konsumsi air dihitung dengan rumus ${ }^{(6)}$ :

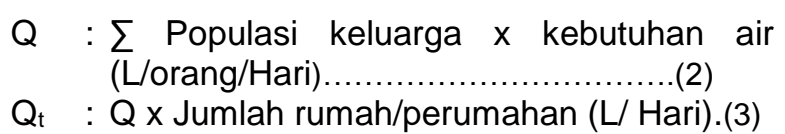


Keterangan

$Q$ : kebutuhan konsumsi air bersih/keluarga

$Q_{t}$ : kebutuhan konsumsi air bersih/perumahan

Identifikasi sumber lain pemenuhan air (substitusi) diperoleh dengan menggunakan rumus sebagai berikut:

1) Substitusi yang bersumber dari air hujan (SNI 03-2453-2002)

$$
\mathrm{V}_{\mathrm{ab}}: 0,855 \times \mathrm{C} \times \mathrm{A} \times \mathrm{R}
$$

\section{Keterangan}

$\mathrm{V}_{\mathrm{ab}}$ : Volume air hujan ( $\mathrm{m}^{3} /$ hari hujan)

C : Konstanta pengairan ( 0.75 untuk daerah beratap)

A : Luas daerah tangkapan air hujan (Atap bangunan) (m2)

R : Curah Hujan harian (mm/jam)

2) Substitusi yang bersumber dari aktivitas lain yang dapat disubstitusi dengan penggunaan air hasil olahan grey water (L/hari)

Qh : Aktivitas x penggunaan/rumah (L/ Hari.(5)

3) Tingkat Efisiensi/ Efisiensi penggunaan air(7)

$E=\frac{Q-\left(V_{a b}+g w\right) \times 100 \%}{Q}$

Keterangan:

E : efisiensi penggunaan air (\%)

Q : konsumsi air bersih/keluarga (L/Hari)

$V_{a b}$ : volume air hujan ( $\mathrm{m}^{3} /$ hari hujan)

Gw : volume air yang dapat disubstitusi oleh grey water (L/hari)

\section{HASIL DAN PEMBAHASAN}

\subsection{Pola Konsumsi Air}

Pemakaian air di tiga perumahan yang ada di Kota Tangerang Selatan, Kota Depok, dan Kota Bogor bervariasi sesuai dengan karakteristik wilayah dan penduduk masingmasing perumahan. Jumlah responden dalam penelitian ini sebanyak 150 responden. Dari hasil tabulasi data yang diperoleh melalui pengukuran dan wawancara langsung dengan responden, pada tiga perumahan diketahui bahwa sumber pemenuhan air bersihnya dikelompokan dalam tiga sumber utama, yaitu air sumur, sambungan PDAM dan sambungan bersama. Sambungan bersama adalah pemakaian 1 buah sumur untuk beberapa rumah tangga. Biaya operasional seperti listrik dan perawatan pompa dibagi rata oleh seluruh rumah tangga yang memakai.

Pada perumahan Selakopi Hijau/ Kehutanan, Kota Bogor, hampir keseluruhan responden menggunakan sambungan PDAM, sehingga pemakaian air tanah lebih sedikit. Penggunaan sambungan air PDAM akan berdampak pada pengurangan pemakaian air tanah yang semakin berkurang keberadaannya sehingga membantu dalam mengkonservasi ketersediaan air tanah. Pemakaian air bersih di tiga perumahan yang ada di Kota Tangerang Selatan, Kota Depok dan Kota Bogor tersaji dalam Tabel 1, 2 dan 3.

Dari hasil pengolahan data yang dilakukan, pemakaian air bersih di Perumahan Villa Bintang Mas, Tangerang Selatan didominasi untuk penggunaaan mandi, cuci muka, dan bersihbersih pribadi $(67,99 \%$ dari total volume pemakaian air bersih), sisanya $3,36 \%$ sampai dengan 14,39\% digunakan untuk penggunaan lainnya (Tabel 1). Pemakaian air bersih oleh rumah tangga di Perumahan Villa Bintang Mas rata-rata per orang per hari membutuhkan 土158,84 Liter/Orang/Hari.

Aktifitas lain terutama aktifitas bersih-bersih dan siram tanaman di perumahan Villa Bintang Mas relatif tidak banyak dilakukan, hal ini terkait dengan luasan rumah yang sebagian besar tidak memiliki lahan untuk taman. Keterbatasan ini dikarenakan rumah yang ada sudah banyak yang mengalami renovasi bangunan sehingga menghabiskan luasan tanah.

Tabel 1. Pemakaian air di Perumahan Villa Bintang Mas, Kota Tangerang Selatan

\begin{tabular}{|c|c|c|c|c|c|}
\hline \multirow{2}{*}{ No } & \multirow{2}{*}{ Aktifitas } & \multicolumn{2}{|c|}{ Liter/Rumah/Hari } & \multirow{2}{*}{$\begin{array}{c}\text { Liter/Orang/Hari } \\
\text { Rata-rata }\end{array}$} & \multirow{2}{*}{$\%$} \\
\hline & & Min & Max & & \\
\hline 1. & Mandi, cuci muka dan bersih bersih pribadi & 85,00 & 431,00 & 444,00 & 67,99 \\
\hline 2. & Aktifitas flushing dan urinal & 18,00 & 144,00 & 51,00 & 7,81 \\
\hline & $\begin{array}{l}\text { Aktifitas dapur (memasak, cuci piring, cuci } \\
\text { sayuran, cuci baju) }\end{array}$ & 11,07 & 245,45 & 94,00 & 14,39 \\
\hline & $\begin{array}{l}\text { Aktifitas bersih-bersih rumah dan siram } \\
\text { tanaman }\end{array}$ & 9,25 & 231,92 & 22,00 & 3,36 \\
\hline & Aktifitas ibadah & 7,67 & 137,84 & 42,00 & 6,43 \\
\hline & Volume pemakaian total & 172,55 & 1.626 .97 & 653,00 & \\
\hline 7. & Volume pemakaian per orang & 64,43 & 448,59 & 158,84 & \\
\hline
\end{tabular}

Keterangan: Tipe perumahan 21 dan 36 
Tabel 2. Pemakaian air di Perumahan Permata Depok, Kota Depok

\begin{tabular}{|c|c|c|c|c|c|}
\hline \multirow{2}{*}{ No } & \multirow{2}{*}{ Aktifitas } & \multicolumn{2}{|c|}{ Liter/Rumah/Hari } & \multirow{2}{*}{$\begin{array}{c}\text { Liter/Orang/Hari } \\
\text { Rata-rata }\end{array}$} & \multirow{2}{*}{$\%$} \\
\hline & & Min & Max & & \\
\hline 1. & Mandi, cuci muka dan bersih bersih pribadi & 135.00 & 429.00 & 338,23 & 49.88 \\
\hline 2. & Aktifitas flushing dan urinal & 21.00 & 160.00 & 58.94 & 8.69 \\
\hline & $\begin{array}{l}\text { Aktifitas dapur (memasak, cuci piring, cuci } \\
\text { sayuran, cuci baju) }\end{array}$ & 10.15 & 336.39 & 101.32 & 14.94 \\
\hline & Aktifitas bersih-bersih dan siram tanaman & 10.50 & 178.74 & 18.89 & 2.78 \\
\hline 5. & Aktifitas ibadah & 13.20 & 245.23 & 52.92 & 7.80 \\
\hline & Volume pemakaian total & 76.07 & $1,811.50$ & 678.04 & \\
\hline 7. & Volume pemakaian per orang & 48.00 & 400.00 & 161.51 & \\
\hline
\end{tabular}

Keterangan: Tipe perumahan 36 dan 42

Tabel 3. Pemakaian air di Selakopi Hijau/ Kehutanan, Kota Bogor

\begin{tabular}{|c|c|c|c|c|c|}
\hline \multirow{2}{*}{ No } & \multirow{2}{*}{ Aktifitas } & \multicolumn{2}{|c|}{ Liter/Rumah/Hari } & \multirow{2}{*}{$\begin{array}{c}\text { Liter/Orang/Hari } \\
\text { Rata-rata }\end{array}$} & \multirow{2}{*}{$\%$} \\
\hline & & Min & Max & & \\
\hline 1. & Mandi, cuci muka dan bersih bersih pribadi & 41.56 & $1,254.89$ & 407.14 & 46.32 \\
\hline 2. & Aktifitas flushing dan urinal & 4.00 & 150.00 & 35.82 & 4.07 \\
\hline 3. & $\begin{array}{l}\text { Aktifitas dapur (memasak, cuci piring, cuci } \\
\text { sayuran, cuci baju) }\end{array}$ & 36.00 & 10.55 & 313.21 & 35.63 \\
\hline 4. & Aktifitas bersih-bersih dan siram tanaman & 19.68 & 908.96 & 84.00 & 9.55 \\
\hline 5. & Aktifitas ibadah & 4.16 & 666.00 & 69.11 & 7.87 \\
\hline 6. & Volume pemakaian total & 133.00 & $2,333.00$ & 878.82 & \\
\hline 7. & Volume pemakaian per orang & 50.00 & 583.25 & 215.38 & \\
\hline
\end{tabular}

Keterangan: Tipe perumahan 36 dan 70

Sumber pemenuhan air bersih di perumahan ini dikategorikan tiga, yaitu dari sambungan bersama, PDAM dan Sumur. Jaringan PDAM baru saja masuk di perumahan Permata Depok, sehingga belum semua rumah memiliki sambungan PDAM yang merata. Masih ada sebagian rumah yang menggunakan air sumur dan sambungan air bersama yang digunakan untuk aktifitas sehari-hari.

Pengambilan sampel data pemakaian air di Kota Bogor dilakukan di Perumahan Selakopi Hijau dan Kehutanan, Kelurahan Pasir Mulya, Kecamatan Bogor Barat, Kota Bogor. Dari hasil tabulasi data pemakaian air diperoleh data, bahwa aktifitas mandi, cuci muka dan bersih bersih pribadi mendominasi keseluruhan pemakaian air yaitu sebesar $46,32 \%$. Aktifitas lainnya berkisar antara $4,07 \%$ hingga $35,63 \%$. Rata-rata penggunaan air bersih per orang per hari di perumahan Selakopi dan Kehutanan sebesar $\pm 215,38$ Liter/Orang/Hari.

Di Kota Bogor, yang dijadikan sebagai sumber penggunaan air rumah tangga, hampir keseluruhannya menggunakan sambungan PDAM. Di perumahan ini, penggunaan air untuk aktifitas bersih-bersih dan siram tanaman cukup tinggi sebesar $9,55 \%$ apabila dibandingkan dengan kedua perumahan lainnya. Hal ini terkait dengan ketersediaan luasan taman dan pekarangan rumah yang cukup tersedia. Mengacu pada Standar Nasional Indonesia
(SNI) 8153;2015 tentang sistem plumbing kebutuhan domestik yang dikeluarkan oleh Kementerian Pekerjaan Umum dan Perumahan Rakyat tahun 2015, kebutuhan air bersih ratarata per orang per hari di tiga perumahan sebesar $\pm 158,84 \quad$ Liter/Orang/Hari sampai dengan $\pm 215,38$ Liter/Orang/Hari masih diatas standar yang ditetapkan sebesar 120 Liter/Orang/Hari, Sedangkan menurut Indriastuti dan Widjonarkokebutuhan air tersebut digolongkan kedalam kota metropolitan $150 \mathrm{~s} / \mathrm{d}$ $>210$ Liter/Orang/ Hari ${ }^{(8)}$.

\subsection{Faktor Yang Mempengaruhi Pemakaian Air}

3.2.1. Faktor yang mempengaruhi pemakaian air per rumah tangga

Berdasarkan hasil analisis statistik bisa diartikan bahwa $98,8 \%$ volume pemakaian air dapat dijelaskan dari perubahan variabel independennya $\left(R^{2}=0,988, p<0.01\right)$. Sisanya $1,2 \%$ dijelaskan oleh faktor lain diluar variabel independen tersebut. Konsumsi air rumah tangga dipengaruhi secara signifikan oleh variabel usia responden, luas atap rumah, pendapatan responden, aktivitas mandi dll, aktivitas flushing, aktivitas dapur, aktivitas bersih-bersih, dan aktivitas ibadah (Tabel 4). Dari tabel 4 dapat diinterpretasikan bahwa setiap pertambahan usia responden satu tahun 
akan mengurangi jumlah konsumsi air rumah tangga sebanyak 0,6 liter. Pada variabel luas tangkapan dapat didefinisikan setiap pertambahan luas tangkapan air satu satuan akan menambah konsumsi air rumah tangga sebanyak 1,12 liter. Variabel berikutnya yaitu pendapatan responden, setiap kenaikan pendapatan responden akan mengurangi konsumsi air sebanyak 6,36 liter. Responden dengan pendapatan tinggi cenderung menggunakan peralatan cuci dan mandi yang efisien dalam penggunaan air seperti shower. Perubahan perilaku dari menggunakan gayung menjadi menggunakan shower adalah salah satu kegiatan program hemat air(9). Kemudian pada variabel aktivitas mandi, cuci muka dan bersih-bersih yang bertambah satu satuan waktu akan menambah jumlah konsumsi air sebanyak 1,05 liter. Demikian juga dengan aktivitas flushing, aktivitas di dapur, aktivitas siram tanaman, dan aktivitas ibadah seperti wudhu, setiap penambahan aktivitas tersebut satu satuan waktu akan menambah konsumsi air sebanyak masing-masing secara berurutan adalah 1,47; 0,97; 0,99; dan 0,11 liter.

Perubahan setiap variabel independen tersebut berlaku bilamana variabel independen yang lain konstan atau tetap. Pada model estimasi ini yang memberikan pengaruh paling besar terhadap perubahan konsumsi air dalam rumah tangga adalah pendapatan responden atau pendapatan dalam rumah tangga. Beberapa faktor yang dapat mempengaruhi pengunaan air dalam rumah tangga adalah pendapatan rumah tangga, usia, gender, dan pendidikan ${ }^{(10)}$. Hasil penelitian Berk et al. menemukan bahwa semakin tinggi pendidikan seseorang dan semakin tinggi pendapatannya ${ }^{(11)}$, maka mereka akan lebih efisien dalam menggunakan air. Hal ini kemungkinan berhubungan dengan kemampuan mereka untuk membeli peralatan yang hemat air

Tabel 4. Hasil estimasi faktor-faktor yang mempengaruhi volume pemakaian air per rumah tangga

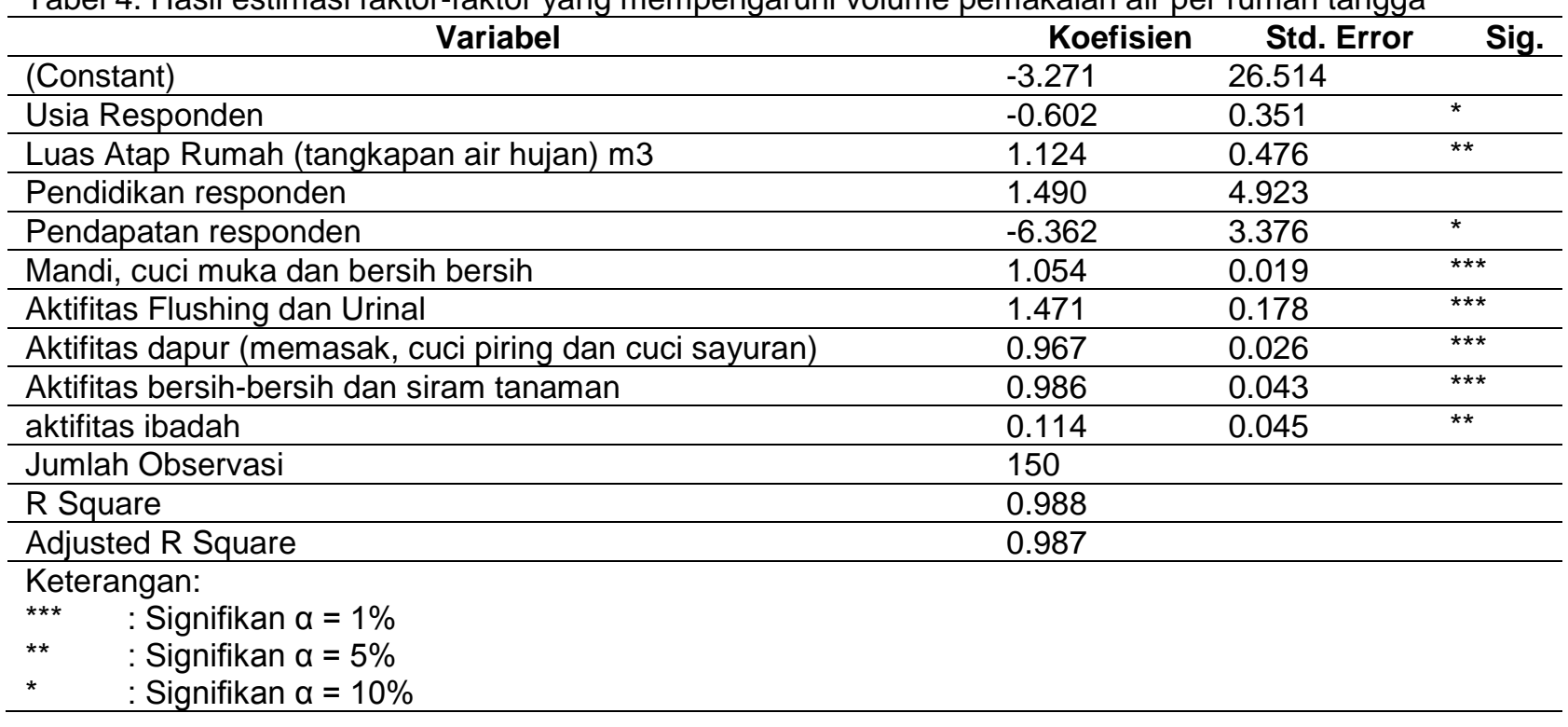

\subsubsection{Karakteristik Responden}

Berdasarkan hasil survei yang dilakukan, karateristik responden sebagian besar (61\%) berjenis kelamin perempuan, sedangkan sisanya (39\%) merupakan laki-laki. Berdasarkan tingkat Pendidikan, sebagian besar masyarakat $(45 \%)$ memiliki tingkat pendidikan SMU, diikuti Sarjana (36\%), sedangkan sisanya berturutturut SMP, S2, SD dan S3.

Berdasarkan Tingkat Pekerjaan sebagian besar (44\%) bekerja di sektor Swasta (44\%), Ibu rumah tangga $(28 \%)$, diikuti oleh PNS dan lainnya $(11 \%)$, sisanya pedagang $(4 \%)$ serta buruh dan pensiunan masing masing sebesar (1\%).

Berdasarkan tingkat pendapatan, sebagian besar responden berada pada rentang pendapantan 2,1-4 Juta (42\%), diikuti rentang pendapatan berturut-turut 4,1-6 Juta (21\%), 0-2 Juta (17\%), 8,1-10 juta (9\%), 6,1-8 juta (7\%) dan sisanya $<2$ juta $(4 \%)$.

Berdasarkan hasil estimasi diperoleh informasi bahwa perubahan konsumsi air per orang dalam suatu rumah tangga bisa dijelaskan oleh model $\left(R^{2}=0,715, \quad p<0,01\right)$. Aktivitas mandi, aktivitas dapur, dan aktivitas bersih-bersih berpengaruh signifikan terhadap konsumsi air per orang $(p<0,01)$. 


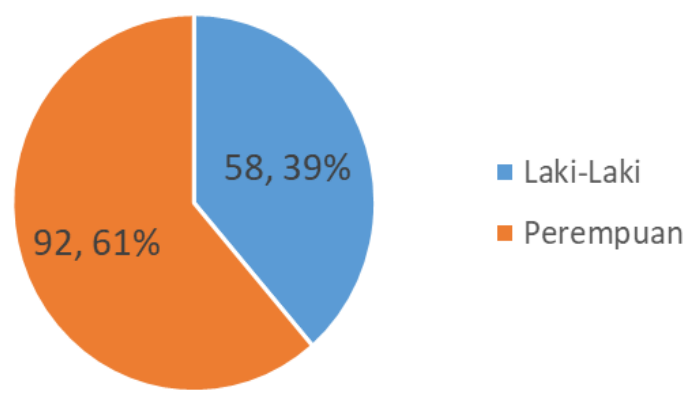

Gambar 1. Jenis Kelamin Responden

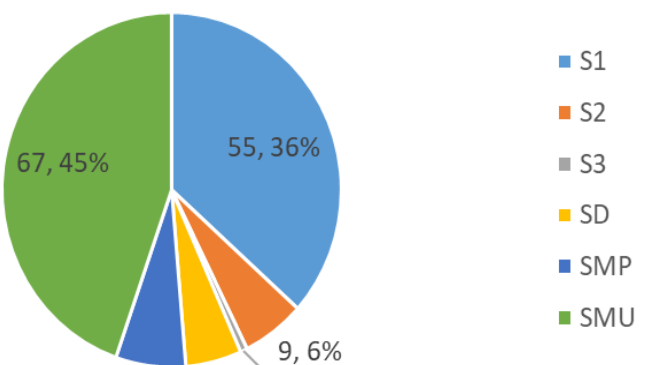

$10,7 \% 8,5 \% 11,1 \%$

Gambar 2. Responden Berdasarkan Tingkat Pendidikan

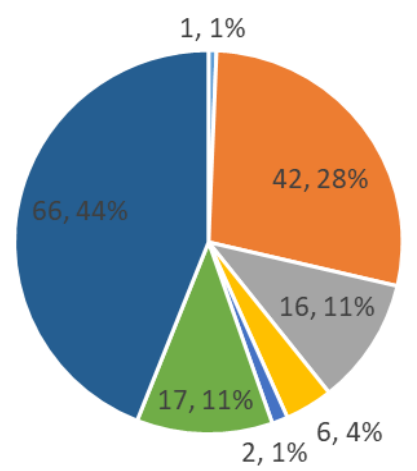

- Buruh

- IBU RT

- Lainnya

- Pedangang

- Pensiunan

- PNS

- Swasta

Gambar 3. Responden Berdasarkan Tingkat Pekerjaan

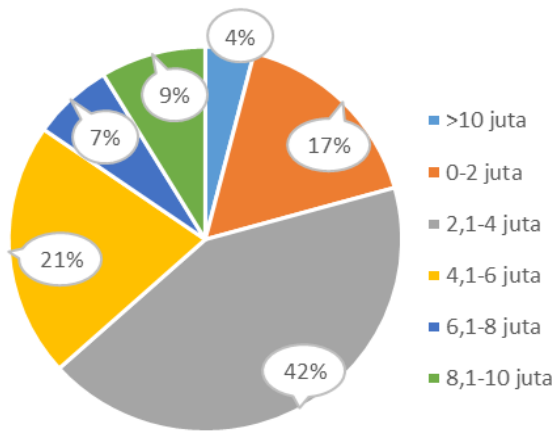

Gambar 4. Responden Berdasarkan Tingkat Pendapatan 


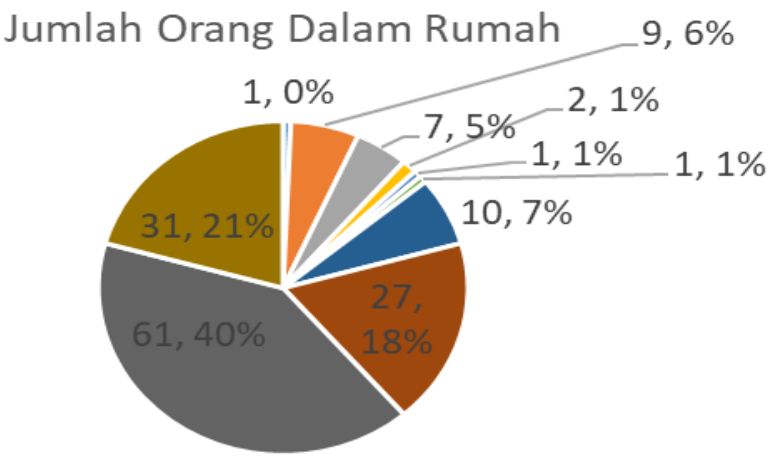

$$
\begin{aligned}
& =5 \text { Orang }-6 \text { Orang }=7 \text { Orang }=8 \text { Orang }=10 \text { Orang } \\
& =1 \text { Orang }=2 \text { Orang }=3 \text { Orang }=4 \text { Orang }=5 \text { Orang }
\end{aligned}
$$

Gambar 5. Responden Berdasarkan Jumlah Orang/Rumah

Tabel 5. Hasil estimasi faktor-faktor yang mempengaruhi volume pemakaian air per orang

\begin{tabular}{llll}
\hline Model & Koefisien & Standar Error & Signifikansi \\
\hline (Constant) & 7.653 & 28.653 & \\
\hline Usia Responden & 0.338 & 0.379 & \\
\hline${\text { Luas Tangkapan } \mathrm{m}^{3}}^{\text {Pendidikan responden }}$ & 0.514 & 0.515 & \\
\hline Pendapatan responden & 6.692 & 5.321 & \\
\hline Mandi, cuci muka dan bersih bersih & -3.006 & 3.648 & \\
\hline Aktifitas Flushing dan Urinal & 0.225 & 0.021 & \\
\hline Aktifitas dapur (memasak, cuci piring dan cuci & -0.270 & 0.192 & \\
sayuran) & 0.117 & 0.028 & \\
\hline Aktifitas bersih-bersih dan siram tanaman & 0.288 & 0.047 & \\
\hline aktifitas ibadah & 0.042 & 0.048 & \\
\hline Jumlah Observasi & 150 & & \\
\hline R Square & 0.715 & & \\
\hline Adjusted R Square & 0.697 & & \\
\hline Keterangan: & & & \\
$\quad$ : Signifikan $\alpha=1 \%$ & & & \\
\hline
\end{tabular}

Dari tabel terlihat bahwa, variabel aktivitas mandi yang meningkat satu satuan waktu (menit) akan menambah jumlah konsumsi air per kapita sebanyak 0,23 liter. Aktivitas di dapur yang meningkat dalam penggunaan air dalam satu satuan waktu akan menambah konsumsi air per kapita sebanyak 0,12 liter. Pada aktivitas siram tanaman yang meningkat satu satuan waktu akan menambah jumlah konsumsi air per kapita sebanyak 0,29 liter.

\subsection{Tingkat Efisiensi Penggunaan Grey Water dan Sumber Lain (Air Hujan)}

Untuk mengurangi penggunaan air bersih di perumahan, salah satu alternatif yang dapat dilakukan melalui pemanfaaatan grey water dan air hujan. Pemanfaatan grey water dalam aktifitas sehari-hari akan berdampak terhadap penurunan penggunaan air bersih. Pemanfaatannya terbatas pada penggunaan air yang tidak membutuhkan kualitas air tertentu, akan tetapi lebih mementingkan pada jumlah air yang diperlukan. Pemakaian grey water memang belum menjadi kebiasaan di kalangan masyarakat umum. Hal ini tidak terlepas dari perilaku masyarakat yang sudah terbiasa menggunakan air untuk satu kali penggunaan. Indriastuti dan Widjonarko berpendapat bahwa masyarakat perlu beradaptasi apabila ada perubahan dengan pola konsumsi air(8). Persepsi dan keragu-raguan masyarakat terhadap grey water masih terpola dalam pemikiran sebagian besar masyakarat, bahwa grey water merupakan air sisa limbah domestik yang kotor. Untuk pemakaian air yang lebih memerlukan kualitas dan tidak membutuhkan kualitas air yang baik, greywater merupakan sumber yang potensial. Selain grey water, potensi air hujan di wilayah perkotaan masih banyak yang belum termanfaatkan dengan maksimal. Air hujan yang turun masih banyak dibiarkan mengalir kedalam tanah atau saluran 
air tanpa dilakukan pemanfaatan lebih lanjut untuk meningkatkan nilai tambah dari air hujan itu sendiri. Rinka et al. menyatakan bahwa pemanfaatan air hujan dapat menghemat $34 \%$ penggunaan air baku ${ }^{(12)}$. Penggunaan air hujan dapat dijadikan sebagai alternatif untuk berbagai aktifitas konsumsi air bersih masyarakat.

Penggunaan grey water yang dimanfaatkan secara bersama-sama dengan air hujan diharapkan dapat mengurangi pemakaian air bersih oleh rumah tangga yang saat ini pemakaiannya terus meningkat. Admadhani et al. melaporkan bahwa laju konsumsi air bersih oleh masyarakat untuk penggunaan domestik telah mengalami peningkatan sebesar $13,81 \%{ }^{(13)}$. Sehingga pemanfaatan grey water yang dikombinasikan dengan air hujan menjadi salah satu solusi yang baik dalam rangka menurunkan tingkat pemakaian air bersih oleh rumah tangga. Tingkat efisiensi pemanfaatan grey water yang dikombinasikan dengan air hujan pada tiga perumahan tersaji dalam Tabel 6.

Tabel 6. Efisiensi pemanfaatan grey water dan air hujan

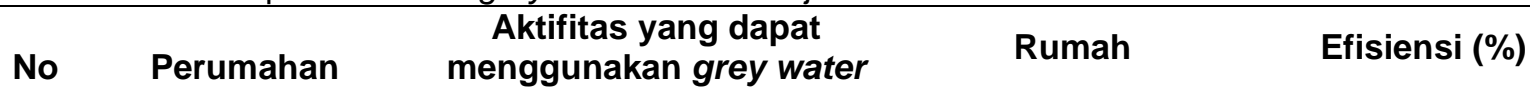

(\%)

\begin{tabular}{|c|c|c|c|c|c|c|}
\hline & & & Tipe 21 & Tipe 36 & Tipe 21 & Tipe 36 \\
\hline (a) & (b) & (c) & (d) & (e) & $(c+d)$ & $(c+e)$ \\
\hline \multirow[t]{2}{*}{1.} & Villa Bintang Mas & $11,17 \%$ & $9,95 \%$ & $17,06 \%$ & $21,12 \%$ & $28,23 \%$ \\
\hline & & & Tipe 36 & Tipe 42 & Tipe 36 & Tipe 42 \\
\hline \multirow[t]{2}{*}{2.} & Permata Depok & $11,47 \%$ & $30,63 \%$ & $35,74 \%$ & $42,1 \%$ & $47,21 \%$ \\
\hline & & & Tipe 36 & Tipe 70 & Tipe 36 & Tipe 70 \\
\hline & $\begin{array}{l}\text { Selakopi Hijau/ } \\
\text { Kehutanan }\end{array}$ & $13,63 \%$ & $23,06 \%$ & $44,84 \%$ & $36,69 \%$ & $58,47 \%$ \\
\hline
\end{tabular}

Sumber: Hasil pengolahan data primer, 2018

Dari hasil pengolahan data yang dilakukan
di tiga perumahan, potensi efisiensi pemanfaatan grew water untuk mengurangi penggunaan air bersih masih cukup rendah. Tingkat efisiensinya hanya berkisar antara $11,17 \%$ sampai dengan $13,63 \%$. Nilai ini masih cukup rendah, sebab penggunaan grey water terbatas pada aktifitas siram-siram tanaman dan bersih-bersih yang tidak memerlukan kualitas air yang bagus.

Sedangkan potensi efisiensi pemanfaatan air hujan di Tangerang Selatan untuk perumahan dengan tipe 21 hanya berpotensi sebesar 9,95 \% dan tipe 36 sebesar 17,06 \% (Tabel 6). Perumahan Permata Depok potensi efisiensinya lebih tinggi bila dibandingkan dengan Villa Bintang Mas. Rumah dengan tipe 36 memiliki potensi efisiensi sebesar 30,63\%, sedangkan rumah dengan tipe 42 memiliki potensi efisiensi sebesar 35,74\% (Tabel 8). Di Kota Bogor, tingkat potensi efisiensinya untuk tipe 36 hanya sebesar 23,06\% dan 44,84\% untuk perumahan dengan tipe 70 (Tabel 6).

Berdasarkan hasil analisis, tingkat efisiensi grey water yang digabungkan dengan air hujan di Kota Depok memiliki efisiensi yang paling tinggi untuk mengurangi penggunaan air bersih dibandingkan kedua perumahan lainnya. Rentang efisiensi total yang didapat sebesar $21,12 \%$ s/d 47,21\%. Nilai terendah berada di Perumahan Villa Bintang Mas sebesar 21,12\%, sedangkan nilai yang tertinggi berada di
Perumahan Selakopi Hijau sebesar 47,21\%. rincian secara lengkap dapat terlihat sebagaimana tabel 6. Hal ini disebabkan perbandingan antara pemakaian air baku dengan jumlah grey water dan curah air hujan di perumahan Selakopi Hijau lebih tinggi daripada perumahan Villa Bintang Mas.

Penggunaan grey water di masyarakat dapat ditingkatkan penggunaannya apabila kualitas grey water yang dihasilkan telah mengalami perbaikan dalam kualitas airnya. Masyarakat meyakini bahwa pemakaian air untuk pemenuhan sehari-hari harus steril dan suci menjadi salah satu yang membatasi pemakaian greywater di masyakarat. Sutyasmi berpendapat bahwa penggunaan grey water dapat menjadi suatu langkah preventifuntuk mengurangi produksi limbah dan pencemaran lingkungan(14). Meskipun memerlukan proses adaptasi dalam penerapannya, edukasi yang lebih intensif dari pemerintah tentang pemanfaatan grey water dapat dijadikan langkah positif dalam penghematan penggunaan air bersih/ air tanah. Lebih lanjut Mantarisa, berpendapat bahwa pengaruh media masa dan elektronika sangat berpengaruh nyata dalam perubahan pola konsumsi masyarakat ${ }^{(15)}$. Nilai efisiensi ini dapat ditingkatkan dengan adanya penyesuaian sistem perpipaan serta pengolahan grey water yang ada di perumahan. Penyesuaian sistem perpipaan dapat memaksimalkan penangkapan air hujan yang 
turun. Pengolahan grey water diharapkan dapat meningkatkan kualitas air grey water, sehingga penggunaannya dapat diperluas.

\section{KESIMPULAN}

Kebutuhan air bersih di tiga perumahan berkisar pada rentang nilai antara $\pm 158,84$ Liter/Orang/Hari sampai dengan $\pm 215,38$ Liter/Orang/Hari. Mengacu pada Standar Nasional Indonesia (SNI) 8153;2015 tentang sistem plumbing kebutuhan domestik yang dikeluarkan oleh Kementerian Pekerjaan Umum dan Perumahan Rakyat tahun 2015 masih diatas standar yang ditetapkan sebesar 120 Liter/Orang/Hari.

Konsumsi air per rumah tangga dipengaruhi secara signifikan oleh variabel usia responden, luas tangkapan rumah, pendapatan responden, aktivitas mandi, aktivitas flushing, aktivitas dapur, aktivitas bersih-bersih, dan aktivitas ibadah, sedangkan konsumsi air per orang hanya dipengaruhi secara signifikan oleh aktivitas mandi, aktivitas dapur, dan aktivitas bersihbersih.

Tingkat efisiensi pemanfaatan grey water dan air hujan dalam mengurangi pemakaian air bersih di tiga perumahan berkisar antara $21,12 \%$ hingga $58,47 \%$.

\section{PERSANTUNAN}

Penulis menyampaikan terima kasih kepada tim Penelitian Pola Konsumsi Air dan Efisiensi Pemanfaatan Air Limbah Rumah Tangga (grey water) dalam pengumpulan data, Puslitbang Kualitas dan Laboratorium Lingkungan atas dukungan pembiayaan penelitian, Kelurahan Pondok Jaya Kota Depok, Kelurahan Pasir Mulya Kota Bogor, Kelurahan Keranggan Kota Tangerang Selatan, dan semua pihak yang terlibat dalam penyusunan dan penulisan jurnal ini.

\section{DAFTAR PUSTAKA}

1. Hasan, A. (2014). Pola konsumsi air bersih pada kampus politeknik negeri sriwijaya. Pilar, 10(1).

2. Direktorat Jenderal (Ditjen) Cipta Karya. (1996). Kriteria perencanaan analisis kebutuhan air. Jakarta.

3. Pam Jaya. (2016, 15-Jan-2019). Retrieved from:

http://pamjaya.co.id/id/others/news/dki_await s_water_supply_from_water_treatment_plan t_buaran_3-121.

4. R. Safitri, R. Purisari, and M. Mashudi, "Pembuatan Biopori dan Sumur Resapan untuk Mengatasi Kekurangan Air Tanah di
Perumahan Villa Mutiara, Tangerang Selatan," Agrokreatif, vol. 5, no. 1, pp. 3947, 2019

5. 5. Nakagawa, N., Otaki, M., Miura, S., Hamasuna, H., \& Ishizaki, K. (2006). Field survey of a sustainable sanitation system in a residential house. Journal of Environmental Sciences (China). https://doi.org/10.1016/S10010742(06)60044-2

6. Noerbambang, S. M., \& Morimura, T. (1991). Perancangan dan pemeliharaan sistem plambing. Jakarta: Pradnya Paramita.

7. Pinandari, A. W., Fitriana, D. N., Nugraha, A., \& Suhartono, E. (2011). Uji Efektifitas dan efisiensi filter biomassa menggunakan sabut kelapa (Cocos Nucifera) Sebagai bioremoval untuk menurunkan kadar logam $(\mathrm{Cd}, \mathrm{Fe}, \mathrm{Cu})$, Total padatan tersuspensi (TSS)dan meningkatkan $\mathrm{pH}$ pada limbah air asam tambang batubara. Jurnal Presipitasi, $1(1), 1-12$.

8. Indriastuti, W., \& Widjonarko. (2013). Pola konsumsi air bersih pada rumah kost di kawasan pendidikan tinggi Tembalang. Jurnal Teknik PWK, 2(3), 609-618.

9. Wijayanti, T. (2017). Skrining senyawa metabolit sekunder ekstrak rumput mutiara (Hedyotis corymbosa (L.) Lamk.) dengan metode GC-MS. Florea: Jurnal Biologi dan Pembelajarannya, 4(1), 24-35.

10. Jorgensen, B., Graymore, M., \& O'Toole, K. (2009). Household water use behavior: An integrated model. Journal of Environmental Management, 91(1), 227-236.

11. Berk, R. A., Cooley, T. F., LaCivita, C. J., Parker, S., Sredl, K., \& Brewer, M. (1980). Reducing consumption in periods of acute scarcity: the case of water. Social Science Research, 9(2), 99-120.

12. Rinka, D. Y., Sururi, M. O. H. R., \& Wardhani, E. K. A. (2014). Perencanaan sistem plambing air limbah dengan penerapan konsep green building pada gedung Panghegar Resort Dago Golf-Hotel \& Spa, 2(2), 1-12.

13. Admadhani, D. N., Hajil, A. H. S., \& Susanawati, L. D. (2013). Analysis of water supply and water demand for carrying capacity assessment (case study of Malang). Jurnal Sumber Daya Alam Dan Lingkungan, 13-20.

14. Sutyasmi, S. (2014). Pemanfaatan kembali air limbah terolah dengan sistem wetland 
untuk pembuatan kulit glace. Majalah Kulit, Karet dan Plastik, 30(Juni), 15-22.

15. Getri Mantarisa, R. (2011). Analisis pola konsumsi dan kecukupan air pada siswa sekolah Dasar Negeri Empang 1 Bogor. Institut Pertanian Bogor, Bogor 